\title{
Risk factors for default from tuberculosis treatment in HIV-infected individuals in the state of Pernambuco, Brazil: a prospective cohort study
}

\author{
Magda Maruza ${ }^{1 *}$, Maria FP Militão Albuquerque², Isabella Coimbra', Líbia V Moura', Ulisses R Montarroyos', \\ Demócrito B Miranda Filho ${ }^{3}$, Heloísa R Lacerda', Laura C Rodrigues ${ }^{4}$ and Ricardo AA Ximenes ${ }^{1,3}$
}

\begin{abstract}
Background: Concomitant treatment of Human Immunodeficiency Virus (HIV) infection and tuberculosis (TB) presents a series of challenges for treatment compliance for both providers and patients. We carried out this study to identify risk factors for default from TB treatment in people living with HIV.

Methods: We conducted a cohort study to monitor HIV/TB co-infected subjects in Pernambuco, Brazil, on a monthly basis, until completion or default of treatment for TB. Logistic regression was used to calculate crude and adjusted odds ratios, 95\% confidence intervals and $P$-values.

Results: From a cohort of 2310 HIV subjects, 390 individuals (16.9\%) who had started treatment after a diagnosis of TB were selected, and data on 273 individuals who completed or defaulted on treatment for TB were analyzed. The default rate was $21.7 \%$ and the following risk factors were identified: male gender, smoking and CD4 T-cell count less than 200 cells $/ \mathrm{mm}^{3}$. Age over 29 years, complete or incomplete secondary or university education and the use of highly active antiretroviral therapy (HAART) were identified as protective factors for the outcome.

Conclusion: The results point to the need for more specific actions, aiming to reduce the default from TB treatment in males, younger adults with low education, smokers and people with CD4 T-cell counts $<200$ cells/ $\mathrm{mm}^{3}$. Default was less likely to occur in patients under HAART, reinforcing the strategy of early initiation of HAART in individuals with TB.
\end{abstract}

\section{Background}

Tuberculosis (TB) is the leading cause of morbidity and death among people living with Human Immunodeficiency Virus (HIV), particularly in developing countries [1]. Brazil is one of 22 countries with a high TB burden [2] and has about 50 million people infected with $M y c o-$ bacterium tuberculosis [3]. Approximately $14 \%$ of patients with TB are co-infected with HIV [4]. The State of Pernambuco has the sixth-highest incidence of TB in the country (44.96 per 100,000 inhabitants) and the second highest TB mortality rate (3.7 per 100,000 inhabitants) [5]. In 2008, the percentage of default from TB

\footnotetext{
* Correspondence: magdamaruza@yahoo.com.br

'Department of Tropical Medicine, Universidade Federal de Pernambuco, Recife, Brazil

Full list of author information is available at the end of the article
}

treatment in Pernambuco was $11.1 \%$, increasing to 18.3\% among subjects co-infected with HIV [6].

Since 1996, Brazil has guaranteed access to antiretroviral treatment (ART) to all HIV subjects. Concomitant treatment of HIV and TB presents a series of challenges, including a long treatment duration, high frequency of drug administration, potential complex interactions of the drugs, toxicity of the two therapies, and the occurrence of immune reconstitution syndrome $[7,8]$.

Default from TB treatment is associated with a longer period of TB transmission, treatment failure and mortality. Identification of risk factors for default and subsequent intervention strategies are required, and are particularly important in HIV subjects because of the increase in morbidity and mortality related to progression of the HIV infection itself. Several studies, using different approaches and methodologies, $[9,10]$ have
C Biomed Central

C 2011 Maruza et al; licensee BioMed Central Ltd. This is an Open Access article distributed under the terms of the Creative Commons Attribution License (http://creativecommons.org/licenses/by/2.0), which permits unrestricted use, distribution, and reproduction in any medium, provided the original work is properly cited. 
been conducted to identify the key risk factors for default from TB treatment in populations that include or do not include HIV subjects [11-17]. However, few studies have prospectively examined risk factors for TB treatment default as the main outcome in a population of HIV subjects [18]. A prospective study design allows a proper selection of the variables, appropriate data collection and more accuracy in assessing the risk factors for treatment default.

This study aimed to estimate the frequency of default from TB treatment in a cohort co-infected with HIV and to identify the risk factors for its occurrence.

\section{Methods}

\section{Design, location and study population}

We conducted a prospective cohort study in HIV subjects older than 18 years who had started treatment after a diagnosis of TB in two referral hospitals for HIV/ AIDS in the state of Pernambuco, Brazil, from June 2007 to December 2009. These two referral centers are responsible for the care of about $70 \%$ of all HIV subjects in the State, and they follow the guidelines of the Brazilian Ministry of Health for the treatment of TB and HIV. In these centers, both treatments are delivered by the same physician. The study excluded patients whose TB diagnosis was changed during follow-up (either because there was no improvement after 2 months of empirical TB treatment or because they were later found to have a different diagnosis).

Default from TB treatment was defined as failure of the patient to attend the clinic for more than 30 consecutive days after the date that the patient was due to return. Treatment failure was identified by a positive smear 4 months after the start of treatment. TB treatment outcomes were defined by the Brazilian Ministry of Health [3]. Successful treatment included cure and completion of treatment.

\section{Cohort recruitment and follow-up}

We enrolled HIV patients in the study at the time they were notified as having tuberculosis the Surveillance System for Infectious Diseases (SINAN/MS), managed by the Brazilian Ministry of Health (MS). Registering the case in the SINAN/MS is a prerequisite for initiation of TB treatment.

We included those patients who were likely to have the opportunity to complete TB treatment before the end of the investigation, i.e., if they started treatment at least 6-8 months before the end of the study. We followed patients monthly until completion of, or default from, TB treatment. A trained health professional interviewed all participants, using a standardized questionnaire, after they gave their informed consent. Additional information was collected from medical records. For patients who defaulted from TB treatment, information was extracted from their medical records, from data of the epidemiological units and from the Mortality Information System to avoid misclassification (with death coded as default).

\section{Definition of terms and study variables}

We considered patients to have a diagnosis of active TB if they had begun TB treatment as a result of clinical suspicion or laboratory confirmation. We considered individuals to be HIV-infected if they had been tested positive for HIV using ELISA, immunofluorescence, Western blotting or rapid test. For the purposes of the analysis, independent variables were grouped into five sections: biological variables; socioeconomic variables; variables relating to habits and lifestyle; variables relating to HIV/AIDS and TB-related variables.

In relation to alcohol consumption, we classified patients as abstainers (never drank or drank less than eight units a year), light drinkers (drank a maximum of two days a week, without exceeding ten units per month), heavy drinkers (drank in excess of five doses a day at least 3 to 4 days a week), and alcohol dependent (undergoing treatment for alcoholism).

In relation to smoking, we classified patients as nonsmokers (never smoked in their lives), former smokers (had stopped smoking at least 6 months prior to study entry), and smokers (smokers at the time of inclusion in the study or had stopped smoking less than 6 months before enrollment).

The criteria used for defining cases of AIDS were those of the Brazilian Ministry of Health [19].

TB treatment was carried out using the following selfadministered regimens: Regimen I (rifampicin, isoniazid and pyrazinamide for 2 months, followed by rifampicin and isoniazid in the last 4 months); Regimen IR (ethambutol introduced in the first 2 months of Regimen I); and other regimens (when rifampicin needed to be replaced by streptomycin and ethambutol because of drug interactions with antiretroviral therapy (ART)) [20]. HAART was defined as the combination of three different antiretroviral drugs, regardless of the number of classes of drugs used. Antiretroviral regimens consisting of two reverse transcriptase inhibitors and efavirenz are the first choice for patients on HAART and rifampicin [20].

\section{Statistical analysis}

The cumulative incidences of TB treatment default, successful treatment, and death were calculated. In the analysis to identify risk factors associated with treatment default, we excluded patients who died during the study period or had not completed TB treatment in time to outcome. 
Univariate logistic regression was used to analyze the association of each study variable with default and successful TB treatment. The magnitude of the association was measured by the odds ratio (OR) and its statistical significance was tested using the OR confidence interval $(\mathrm{CI})$ and the $P$-value (Chi-square test or maximum likelihood ratio). The level of significance was set at $P<0.05$.

We carried out the multivariate analysis in two steps: 1) multivariate analysis of each group to determine the variables closely associated with the outcome: variables associated with the outcome with $P<0.20$ in the univariate analysis were successively included in a multivariate logistic regression model, and those showing an association with a $P$-value $\leq 0.05$ remained in the model; 2) final multivariate model: the variables selected in the previous step were introduced in the final multivariate model (including variables of all groups) and those with a $P$-value $\leq 0.05$ were remained in the final model.

We checked collinearity for those variables which, in theory, were expected to be associated with each other. The variables which remained in the final multivariate model were checked for interaction.

The data entry and double entry validation were performed in parallel with data collection, and the database was managed by the SQL Server 2000 (Microsoft), using GeneXus software (version 7.5). STATA version 8.2 for data analysis.

This study is part of the CSV 182/06 - Clinical-Epidemiological Study of TB/HIV Co-infection Project in Recife, approved by the research ethics committee of The Universidade Federal de Pernambuco (registration number at SISNEP FR-067 159/CAAE- 0004.1.172.10605/REGISTRATION CEP/CCS/UFPE 254/05).

\section{Results}

From a cohort of 2310 HIV subjects, 566 patients (24.5\%) who had begun treatment after a diagnosis of TB were identified. Of these, 170 individuals (30.0\%) were not enrolled in the study because they were not contactable by the researchers. Six patients were excluded due to changes in their TB diagnosis (four had started on empiric treatment based on clinical presentation but the TB diagnosis was subsequently deemed erroneous, one was later found to have cryptococcal meningitis, and one was later diagnosed with histoplasmosis). A total of 51 patients (9.0\%) started TB treatment during the study period but did not complete treatment in time to assess their outcome. Of the 339 patients studied, 188 (55.5\%) were successfully treated, $85(25.1 \%)$ defaulted from treatment and 66 (19.5\%) died. There was no documented case of treatment failure, and six patients were lost to follow-up.
A total of 273 patients who were successfully treated or defaulted from treatment for TB were included in the analysis, as shown in Figure 1. Comparing the characteristics of the individuals included in the cohort with those who began treatment for TB but were not included in the study (not located by the study staff), we found that the two populations were similar in age (mean age \pm standard deviation of $36.7 \pm 9.6$ years for individuals included in the cohort, versus $37.5 \pm 11.3$ years for those not included, $P=0.2205)$, gender $(P=$ $0.39)$ and TB treatment outcomes $(P=0.991)$.

The age of the study population ranged from 18 to 67 years, with mean of 36.7 years, and $69.7 \%$ were male. Approximately one-fifth (21.7\%) of subjects defaulted from TB treatment. The univariate analysis of the risk factors for defaulting from TB treatment is shown in table 1.

Variables that were significantly associated with treatment default in the multivariate analysis in each group of variables were included in the final multivariate model. The variables that remained in the final model were: sex, age, smoking, education level, CD4 T-cell count and ART (Table 2). No interactions or collinearity were found.

\section{Discussion}

We observed that $21.7 \%$ of HIV subjects receiving TB treatment defaulted from treatment during our study. The risk factors identified for TB treatment default in this cohort were male sex, smoking, and a CD4 count of less than 200 cells $/ \mathrm{mm}^{3}$. Age older than 29 years, complete or incomplete secondary or university education, and the use of ART were identified as protective factors against TB treatment default.

The percentage of TB treatment default found in the present study was higher than the $14 \%$ reported in HIV subjects in Brazil as a whole [21] but similar to those of studies in other countries with a high TB burden. The high rate of default in our study may reflect the fact that health services for patients with HIV/AIDS have neglected to monitor patients who need TB treatment. Furthermore, Directly Observed Therapy (DOT) is not operationally feasible in referral hospitals where patients come from a wide area, such as the whole state of Pernambuco which covers approximately $98485 \mathrm{~km}^{2}$.

It is not clear whether the use of ART has any impact on defaulting from TB treatment [22,23]. The complex potential drug interactions between antiretroviral drugs and drugs used to treat TB could have a negative impact on adherence to treatment for both diseases. However, experts agree that initiation of HAART should not be delayed, because mortality is reduced with early initiation of HAART along with anti-TB treatment [24]. In this study, the use of 


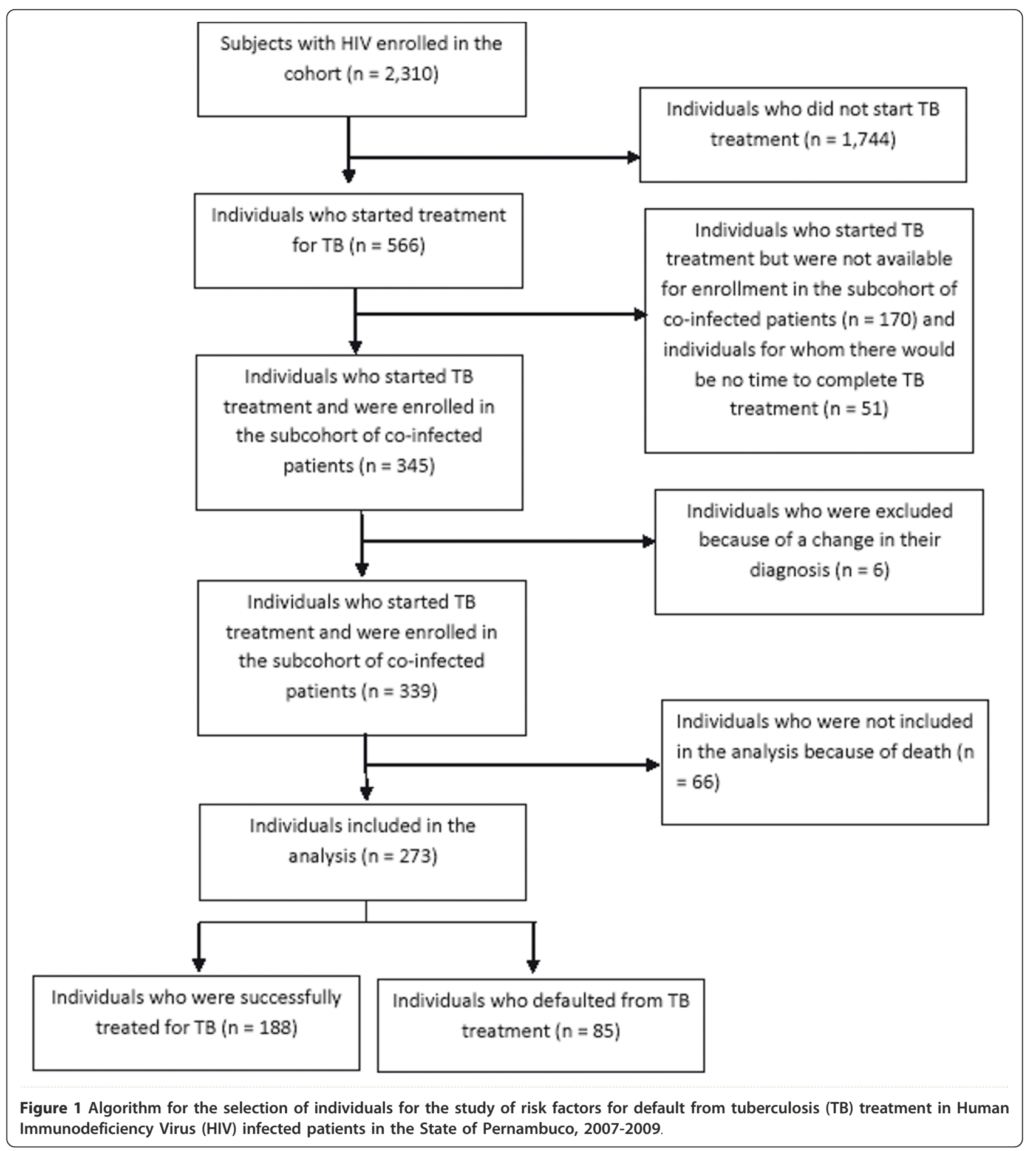

HAART during treatment for TB was a protective factor against default from TB treatment, as described [18] in HIV subjects in Thailand. These findings are relevant because they point to the possibility that the concomitant use of ART and drugs to treat TB does not imply a greater likelihood of defaulting from $\mathrm{TB}$ treatment in HIV subjects.
We also found that being male was a risk factor for TB treatment default. Similar findings have been reported in populations that included individuals with and without HIV [25-28]. However, in our study, male sex was still associated with default from TB treatment even after adjustment for the effect of smoking and alcohol consumption. The explanation to our results 
Table 1 Univariate analysis of the risk factors for defaulting from TB treatment among HIV subjects in the State of Pernambuco, 2007-2009

\begin{tabular}{|c|c|c|c|c|c|c|c|}
\hline \multirow[t]{2}{*}{ VARIABLES } & \multicolumn{2}{|c|}{ Default } & \multicolumn{2}{|c|}{ Treatment success } & \multirow[t]{2}{*}{ OR } & \multirow[t]{2}{*}{$95 \% \mathrm{Cl}$} & \multirow[t]{2}{*}{$P$-value } \\
\hline & $\mathrm{n}$ & $\%$ & $\mathrm{n}$ & $\%$ & & & \\
\hline \multicolumn{8}{|l|}{ BIOLOGICAL } \\
\hline \multicolumn{8}{|l|}{ Sex } \\
\hline Female & 15 & 17.6 & 57 & 30.3 & 1.00 & - & - \\
\hline Male & 70 & 82.3 & 131 & 69.7 & 2.03 & $1.07-3.84$ & 0.030 \\
\hline \multicolumn{8}{|l|}{ Age group } \\
\hline 18 to 29 years & 33 & 38.8 & 35 & 18.6 & 1.00 & - & - \\
\hline 30 to 49 years & 48 & 56.5 & 131 & 69.7 & 0.38 & $0.21-0.69$ & 0.001 \\
\hline 50 years or more & 4 & 4.7 & 22 & 11.7 & 0.19 & $0.06-0.61$ & 0.006 \\
\hline \multicolumn{8}{|l|}{ Race } \\
\hline White & 15 & 17.6 & 42 & 22.3 & 1.00 & - & - \\
\hline Non-white & 70 & 82.3 & 146 & 77.7 & 1.34 & $0.69-2.58$ & 0.378 \\
\hline \multicolumn{8}{|l|}{ SOCIOECONOMIC } \\
\hline \multicolumn{8}{|l|}{ City of Residence } \\
\hline Recife & 39 & 45.9 & 78 & 41.5 & 1.00 & - & \\
\hline Metropolitan Region & 35 & 41.2 & 78 & 41.5 & 0.89 & $0.51-1.56$ & 0.702 \\
\hline Inland & 11 & 12.9 & 32 & 17.0 & 0.68 & $0.31-1.50$ & 0.350 \\
\hline \multicolumn{8}{|l|}{ Marital status } \\
\hline Married & 12 & 14.1 & 54 & 28.7 & 1.00 & - & \\
\hline Single/Separated/Widowed & 73 & 85.9 & 134 & 71.3 & 2.45 & $1.23-4.87$ & 0.011 \\
\hline \multicolumn{8}{|l|}{ Shared residence } \\
\hline Family/Partner & 17 & 20.0 & 33 & 17.6 & 1.00 & & \\
\hline Alone & 68 & 80.0 & 155 & 82.4 & 1.74 & $0.61-2.25$ & 0.629 \\
\hline \multicolumn{8}{|l|}{ Education level } \\
\hline Complete or incomplete primary education & 69 & 81.2 & 128 & 69.1 & 1.00 & - & - \\
\hline Complete or incomplete secondary or university education & 16 & 21.0 & 60 & 31.9 & 0.49 & $0.26-0.92$ & 0.027 \\
\hline \multicolumn{8}{|l|}{ Employment } \\
\hline Yes & 17 & 20.0 & 34 & 18.1 & 1.00 & - & \\
\hline No & 68 & 80.0 & 154 & 81.9 & 0.88 & $0.46-1.68$ & 0.707 \\
\hline \multicolumn{8}{|l|}{ Income* } \\
\hline$<1$ minimum wage & 65 & 22.6 & 117 & 37.4 & 1.00 & - & - \\
\hline$\geq 1$ minimum wage & 19 & 77.4 & 70 & 62.6 & 0.48 & $0.27-0.88$ & 0.017 \\
\hline \multicolumn{8}{|l|}{ HABITS } \\
\hline \multicolumn{8}{|l|}{ Alcohol consumption } \\
\hline None or light drinker & 69 & 81.2 & 177 & 94.1 & 1.00 & - & - \\
\hline Moderate or Heavy drinker & 16 & 18.8 & 11 & 5.8 & 3.73 & $1.64-8.44$ & 0.002 \\
\hline \multicolumn{8}{|l|}{ Smoking status } \\
\hline Never smoked & 22 & 25.9 & 81 & 43.1 & 1.00 & - & - \\
\hline Former smokers & 14 & 16.5 & 45 & 23.9 & 1.14 & $0.53-2.45$ & 0.727 \\
\hline Current smokers & 49 & 57.6 & 62 & 33.0 & 2.90 & $1.59-5.31$ & 0.001 \\
\hline Illicit drug use & & & & & & & \\
\hline No & 63 & 74.1 & 129 & 68.6 & 1.00 & & \\
\hline Yes & 22 & 25.9 & 59 & 31.4 & 0.76 & $0.42-1.35$ & 0.358 \\
\hline HIV VARIABLES & & & & & & & \\
\hline Opportunistic Disease & & & & & & & \\
\hline No & 13 & 15.3 & 32 & 17.0 & 1.00 & - & - \\
\hline Yes & 72 & 84.7 & 156 & 83.0 & 1.13 & $0.56-2.29$ & 0.722 \\
\hline AIDS & & & & & & & \\
\hline No & 3 & 3.5 & 6 & 3.2 & 1.00 & - & \\
\hline Yes & 82 & 96.5 & 182 & 97.0 & 0.90 & $0.21-3.69$ & 0.885 \\
\hline
\end{tabular}


Table 1 Univariate analysis of the risk factors for defaulting from TB treatment among HIV subjects in the State of Pernambuco, 2007-2009 (Continued)

\begin{tabular}{|c|c|c|c|c|c|c|c|}
\hline \multicolumn{8}{|l|}{ CD4 T-cell count ${ }^{*}\left(\right.$ cell $\left./ \mathrm{mm}^{3}\right)$} \\
\hline 200 or more & 33 & 42.3 & 114 & 62.3 & 1.00 & - & - \\
\hline Less than 200 & 45 & 57.7 & 69 & 37.7 & 2.25 & $1.31-3.86$ & 0.003 \\
\hline \multicolumn{8}{|l|}{ Beginning of HAART } \\
\hline Did not start HAART & 33 & 38.8 & 23 & 12.23 & 1.00 & - & - \\
\hline Before treatment for TB & 42 & 49.4 & 96 & 51.1 & 0.30 & $0.16-0.58$ & 0.000 \\
\hline Up to second month of TB treatment & 8 & 9.4 & 41 & 21.8 & 0.13 & $0.05-0.34$ & 0.000 \\
\hline After the second month of TB treatment & 2 & 2.3 & 28 & 14.9 & 0.05 & $0.01-0.23$ & 0.000 \\
\hline \multicolumn{8}{|l|}{ TB VARIABLES } \\
\hline \multicolumn{8}{|l|}{ Setting of beginning of TB treatment } \\
\hline Outpatient clinic & 33 & 38.8 & 88 & 46.8 & 1.00 & - & - \\
\hline Hospital & 52 & 61.2 & 100 & 53.2 & 1.38 & $0.82-2.33$ & 0.220 \\
\hline \multicolumn{8}{|l|}{ TB clinical site } \\
\hline Pulmonary & 57 & 32.4 & 119 & 67.6 & 1.00 & - & - \\
\hline Extra-pulmonary & 19 & 22.3 & 47 & 25.0 & 0.84 & $0.45-1.56$ & 0.591 \\
\hline Disseminated & 9 & 10.6 & 22 & 11.7 & 0.85 & $0.63-1.97$ & 0.369 \\
\hline \multicolumn{8}{|l|}{ Type of regimen for TB treatment } \\
\hline Regimen 1 & 62 & 75.9 & 134 & 71.3 & 1.00 & - & - \\
\hline Regimen $1 \mathrm{R}$ & 19 & 22.3 & 41 & 21.8 & 1.00 & $0.53-1.86$ & 0.996 \\
\hline Other regimens & 4 & 4.7 & 13 & 6.9 & 0.66 & $0.20-2.12$ & 0.491 \\
\hline \multicolumn{8}{|l|}{ Adverse effects } \\
\hline No & 76 & 89.4 & 171 & 91.0 & 1.00 & - & - \\
\hline Yes & 9 & 10.6 & 17 & 9.0 & 1.19 & $0.50-2.79$ & 0.687 \\
\hline \multicolumn{8}{|l|}{ Previous Treatment } \\
\hline No & 39 & 45.9 & 84 & 44.7 & 1.00 & - & - \\
\hline Yes & 46 & 30.7 & 104 & 69.3 & 0.95 & $0.56-1.59$ & 0.853 \\
\hline
\end{tabular}

OR, odds ratio; $\mathrm{Cl}$, confidence interval; HAART, highly active antiretroviral therapy

*The number of individuals varied because of missing values.

might be that women are more motivated to undergo treatment for TB $[29,30]$ and have a greater need and desire to be cured and endure adverse drug reactions during the most critical period [31].

In this study, smoking was identified as an independent risk factor for TB treatment default. Kittikraisak et al. [18] have speculated that, among smokers, chronic respiratory symptoms caused by smoking hinder the improvement in respiratory symptoms secondary to TB, which could lead to a lack of belief in the effectiveness of TB treatment. Another explanation would be that smoking is associated with a lifestyle and risk-related behaviors that influence compliance with medication regimens [32]. Moreover, smoking may also be related to depression and poor adherence to treatment, as described by Webb et al. [33] in HIV subjects taking HAART

Although we found that alcohol consumption was associated with treatment default in the univariate analysis, this variable did not remain in the final multivariate model, probably due to the sample size. Illicit drug use was not significantly associated with TB treatment default, possibly because of the sample size or because of questions on illicit drug use are sensitive questions and may not be answered correctly.

No studies associating a low CD4 T-cell count with TB treatment default were found in the literature. In this study, a CD4 T-cell count of less than 200 cells/ $\mathrm{mm}^{3}$ was associated with a higher frequency of default from TB treatment. Patients with a lower CD4 count are more severely ill and therefore it is probably harder for them to attend clinics and tolerate medications. However, no association between default from TB treatment and other opportunistic diseases was found.

In this study, we identified that complete or incomplete secondary or university education was associated with a lower risk of defaulting from TB treatment. It is believed that a low level of education hinders perception of the seriousness of the disease and causes difficulties in understanding medical guidelines, leading to a lack of compliance with use of prescribed medications, as shown in a study carried out by Natal et al. [16].

One limitation of this study was the fact that not all individuals who began treatment for TB in the two health centers participated in the study. However, the 
Table 2 Final model of the risk factors for defaulting from TB treatment among HIV subjects in the State of Pernambuco, 2007-2009

\begin{tabular}{|c|c|c|c|}
\hline Variables & $\mathrm{OR}_{\text {adj }}$ & $95 \% \mathrm{Cl}$ & $P$-value \\
\hline \multicolumn{4}{|l|}{ Sex } \\
\hline Female & 1.00 & & \\
\hline Male & 2.28 & $1.06-4.94$ & 0.036 \\
\hline \multicolumn{4}{|l|}{ Age group } \\
\hline 18 to 29 years & 1.00 & & \\
\hline 30 years or more & 0.50 & $0.25-0.99$ & 0.047 \\
\hline \multicolumn{4}{|l|}{ Education level } \\
\hline Complete or incomplete primary education & 1.00 & & \\
\hline Complete or incomplete secondary or university education & 0.33 & $0.15-0.71$ & 0.005 \\
\hline \multicolumn{4}{|l|}{ Smoking status } \\
\hline Never smoked & 1.00 & & \\
\hline Former smoker & 1.07 & $0.43-2.67$ & 0.876 \\
\hline Current smoker & 2.62 & $1.31-5.26$ & 0.007 \\
\hline \multicolumn{4}{|l|}{ CD4 T-cell count } \\
\hline 200 or more & 1.00 & & \\
\hline Less than 200 & 2.93 & $1.56-5.23$ & 0.001 \\
\hline \multicolumn{4}{|l|}{ HAART use } \\
\hline Did not start HAART & 1.00 & & \\
\hline Before treatment for TB & 0.32 & $0.15-0.67$ & 0.003 \\
\hline At any time during $\mathrm{TB}$ treatment & 0.12 & $0.05-0.33$ & 0.000 \\
\hline
\end{tabular}

$\mathrm{OR}_{\mathrm{adj}}$, adjusted OR.

Alcohol consumption was included in the final multivariate model but it was subsequently excluded because it was not statistically significant.

inclusion or exclusion of potentially eligible was mainly to the difficulties experienced in recruiting patients. It is believed that this did not interfere with the association found, since a comparison of individuals included and not included in the study showed no differences regarding sex, age, and percentage of success and default from treatment for TB. Another limitation is that, as HIV patients are usually paucibacillary and there were cases of extra-pulmonary TB in the study population, only a few cases had a positive smear and culture at the time of the diagnosis of TB. Therefore, there was no documented case of treatment failure.

\section{Conclusions}

In the present study, we observed a high rate of default from TB treatment, even though both treatments, for HIV infection and TB, were being conducted in the same department responsible for monitoring the patient, a scenario which should have contributed to reducing the default rate in the study population.

The results indicate that there is still need for action to be taken to reduce rates of default from TB treatment in specific groups, in particular males, younger individuals and those with a low level of education. Moderate and heavy drinkers are also a group to be targeted.

The associations of smoking and CD4 T-cell count less than 200 cells $/ \mathrm{mm}^{3}$ with TB treatment default need to be better understood for more appropriate intervention planning to reduce treatment default in these subjects.

An important finding of this study is that the use of HAART was protective against TB treatment default. This reinforces the strategy of early initiation of HAART in HIV individuals with TB.

\section{Acknowledgements}

We are grateful for the financial support of Ministerio da Saude do Brasil/ Programa DST/AIDS/UNESCO (CSV 182/06 - Projeto "Estudo ClinicoEpidemiologico da Co-Infeccao HIV/Tuberculose em Recife"). The authors were partially supported by CNPq (Scholarship 308311/2009-4 to RAAX and Scholarship 301779/2009-0 to MFPMA and scholarship 310911/2009-5 to HRL).

Author details

${ }^{1}$ Department of Tropical Medicine, Universidade Federal de Pernambuco, Recife, Brazil. ²NESC Department, Centro de Pesquisas Aggeu Magalhães/ FIOCRUZ, Recife, Brazil. ${ }^{3}$ Department of Medical Science, Universidade de Pernambuco, Recife, Brazil. ${ }^{4}$ London School of Hygiene and Tropical Medicine, London, UK

\section{Authors' contributions}

MM, MFPMA, IC, LVM, URM, DBMF, HRL, LCR, RAAX, made substantial contributions to the conception and design of the study. IC, LVM, DBMF, HRL supervised the study. RAAX, URM provided statistical support. MM, MFPMA, IC, LVM, URM, DBMF, HRL, LCR, RAAX contributed to the writing of the manuscript. MM, RAAX, MFPMA, LCR critically revised the manuscript. All authors read and approved the final manuscript.

\section{Competing interests}

The authors declare that they have no competing interests. 
Received: 13 December 2010 Accepted: 16 December 2011

Published: 16 December 2011

\section{References}

1. Mayer KH, Hamilton CD: Synergistic Pandemics: Confronting the Global HIV and Tuberculosis Epidemics. CID 2010, 50(S3):S67-S70.

2. WHO: Global tuberculosis control: a short update to the 2009 report. December 2009. Geneva, WHO: 2009.

3. Brasil. Ministério da Saúde. Secretaria de Vigilância em Saúde. Departamento de Vigilância Epidemiológica: Guia de vigilância epidemiológica/Ministério da Saúde, Secretaria de Vigilância em Saúde, Departamento de Vigilância Epidemiológica. Braślia, Ministério da Saúde; 7 2009, 816

4. Brasil. Ministério da Saúde. Secretaria de Vigilância em Saúde: Boletim eletrônico Epidemiológico. Informe Eletrônico da Tuberculose. Brasília, Ministério da Saúde; Ano9, n², Julho; 2009.

5. Brasil. Ministério da Saúde: Série histórica da taxa de incidência de tuberculose. Brasil, Regiões e Unidades Federadas de residência por ano de diagnóstico (1990 a 2009). Brasília, SINAN/SVS/MS; 2010.

6. Pernambuco: Situação da tuberculose em Pernambuco de acordo com o encerramento dos casos 2001-2009. Pernambuco, SINAN/SES/DST-AIDS-PE; 2009.

7. Sterling TR, Pham PA, Chaisson RE: HIV Infection-Related Tuberculosis: Clinical Manifestations and Treatment. CID 2010, 50(S3):S223-S230.

8. Meintjes G, Rabie H, Wilkinson RJ, Cotton MF: Tuberculosis -associated Immune Reconstitution Inflammatory Syndrome and Unmasking of Tuberculosis by Antiretroviral Therapy. Clin Chest Med 2009, 30(4):797-810.

9. Kruk ME, Schwalbe NR, Aguiar CA: Timing of default from tuberculosis treatment: a systematic review. Trop Med Int Health 2008, 13:703-712.

10. Brasil PEA, Braga JU: Meta-analysis of factors related to health services that predict treatment default by tuberculosis patients. Cad Saúde Pública 2008, 24(S4):S485-S502.

11. Santha T, Garg R, Frieden TR, Chandrasekaran V, Subramani R, Gopi PG, Selvakumar N, Ganapathy S, Charles N, Rajamma J, Narayanan PR: Risk factores associated whith default, failure and death among tuberculosis patients treated in a DOTS programme in Tiruvallur District, South India, 2000. Int J Tuberc Lung Dis 2002, 6(9):780-788.

12. Albuquerque MFM, Ximenes RAA, Lucena-Silva N, Souza WV, Dantas AT, Dantas OMS, Rodrigues LC: Factors associated with treatment failure, dropout, and death in a cohort of tuberculosis patients in Recife, Pernambuco State, Brazil. Cad Saúde Pública 2007, 23(7):1573-1582.

13. Makombe SD, Harries AD, Yu JK-L, Hochgesang M, Mhango E, Weigel R, Pasulani O, Fitzgerald M, Schouten EJ, Libamba E: Outcomes of tuberculosis treatment patients who start antiretroviral therapy under routine programme conditions in Malawi. Int I Tuberc Lung Dis 2007, 11(4):412-416.

14. Maruza M, Ximenes RAA, Lacerda HR: Desfecho do tratamento e confirmação do diagnóstico de tuberculose em pacientes com HIV/AIDS no Recife, Pernambuco, Brasil. J Bras Pneumol 2008, 34(6):394-403.

15. Tessema B, Muche A, Bekele A, Reissig D, Emmrich F, Sack U: Treatment outcome of tuberculosis patients at Gondar University Teaching Hospital, Northwest Ethiopia. A five-year retrospective study. BMC Public Health 2009, 9:371.

16. Natal S, Valente J, Gerhardt G, Penna ML: Modelo de predição para o abandono do tratamento da tuberculose pulmonar. Bol Pneumol Sanit 1999, 7(1):65-78.

17. Rabahi MF, Rodrigues AB, Mello FQ, Almeida Netto JC, Kritski AL: Concompliance with tuberculosis treatment by patients at a tuberculosis and AIDS reference hospital in midwestern Brazil. Braz J Infect Dis 2002, 6:63-73.

18. Kittikraisak W, Burapat C, Kaewsa-ard S, Watthanaamornkiet W, Sirinak C, Sattayawuthipong W, Jittimanee S, Pobkeeree V, Varma JK: Factores associated with tuberculosis treatment default among HIV-infected tuberculosis patients in Thailand. Trans R Soc Trop Med Hyg 2009, 103:59-66.

19. Brasil. Ministério da Saúde. Secretaria de Vigilância em Saúde. Programa Nacional de DST e Aids: Critérios de definição de casos de aids em adultos e crianças. Ministério da Saúde, Secretaria de Vigilância em Saúde, Programa Nacional de DST e Aids Brasília, Ministério da Saúde; 2003.

20. Brasil. Ministério da Saúde. Secretária de Vigilância em Saúde. Programa Nacional de DST e Aids: Recomendações para Terapia Anti-retroviral em
Adultos Infectados pelo HIV: 2008/Ministério da Saúde, Secretaria de Vigilância em Saúde, Programa Nacional de DST e Aids. Brasília, Ministério da Saúde; 72008.

21. Comissão de Tuberculose da SBPT, Grupo de Trabalho das Diretrizes para Tuberculose da SBPT: III Diretrizes para Tuberculose da Sociedade Brasileira de Pneumologia e Tisiologia. J Bras Pneumol 2009, 35(10):1018-1048.

22. Lawn SD, Myer $L$, Bekker $L G$, Wood R: Burden of tuberculosis in an antiretroviral treatment programme in sub-Saharan Africa: impact on treatment outcomes and implications for tuberculosis control. AIDS 2006, 20(12):1605-1612.

23. Moore D, Liechty C, Ekwaru P, Were W, Mwima G, Solberg P, Rutherford G, Mermin J: Prevalence, incidence and mortality associated with tuberculosis in HIV-infected patients initiating antiretroviral therapy in rural Uganda. AIDS 2007, 21(6):713-719.

24. Karim SSA, Naidoo K, Grobler A, Padayatchi N, Baxter C, Gray A, Gengiah T, Nair G, Bamber S, Singh A, Khan M, Pienaar J, El-Sadr W, Friedland G, Karim QA: Timing of Initiation of Antiretroviral Drugs during Tuberculosis Therapy. N Engl J Med 2010, 362:697-706.

25. Fatiregun AA, Ojo AS, Bamgboye AE: Treatment outcomes among pulmonary tuberculosis patients at treatment centers in Ibadan, Nigeria. Annals of African Medicine 2009, 8(2):100-104.

26. Lima MB, Mello DA, Morais APP, Silva WC: Estudo de casos sobre abandono do tratamento da tuberculose: avaliação do atendimento, percepção e conhecimentos sobre a doença na perspectiva dos clientes, Fortaleza, Ceará, Brasil, 1996. Cad Saude Publica 2001, 17(4):877-85.

27. Naing NN, D'Este C, Isa AR, Salleh R, Bakar N, Mahmod MR: Factors contributing to poor compliance with anti-TB treatment among tuberculosis patients. Southeast Asian I Trop Med Public Health 2001, 32:369-82

28. Salami AK, Oluboyo PO: Management outcome of pulmonary tuberculosis: a nine year review in llorin. West Afr J Med 2003, 22:114-9.

29. de VoS PF: Tuberculosis, adherence behaviour the inner city [Master's thesis]. Edmonton (Alberta), University of Alberta; 2002, 221.

30. Matebesi Z: Living with TB: The career of the tuberculosis patient in the free state, SA [PhD dissertation]. Bloemfontein (South Africa), University of the Free State; 2004, 216.

31. Gonçalves H, Costa JSD, Menezes AMB, Knauth D, Leal OF: Adesão à terapêutica da tuberculose em Pelotas, Rio Grande do Sul: na perspectiva do paciente. Cad Saúde Pública 1999, 15(4):777-787.

32. Jessor R: New perspectives on adolescent risk behavior. In New perspectives on adolescent risk behavior. Edited by: Jessor R. Cambridge, England: Cambridge University Press; 1998:1-10.

33. Webb MS, Vanable PA, Carey MP, Blair DC: Medication adherence in HIVinfected smokers: the mediating role of depressive symptoms. AIDS Education and Prevention 2009, 21(SA):94-105.

\section{Pre-publication history}

The pre-publication history for this paper can be accessed here: http://www.biomedcentral.com/1471-2334/11/351/prepub

doi:10.1186/1471-2334-11-351

Cite this article as: Maruza et al: Risk factors for default from tuberculosis treatment in HIV-infected individuals in the state of Pernambuco, Brazil: a prospective cohort study. BMC Infectious Diseases 2011 11:351. 